\title{
使用済み燃料横型サイロ貯蔵施設の基本設計
}

\author{
南了悟* 中田哲夫* 高橋伸行**
}

横型サイロ貯蔵施設は, 米国で実用化された軽水炉の使用済み燃料乾式貯蔵システムであり，我が国の使用済み燃料 中間貯蔵施設の候補概念の一つであることから，経済性向上，日本の安全審査指針・技術基準，貯蔵燃料の仕樣，耐震 条件等との適合性を考慮して, 我が国向けの横型サイロ貯蔵施設の開発を進めてきた。

横型サイロ貯蔵施設の設計に当たっては, 日本の条件に適合させるため, 除熱性向上, 遮へい性能向上, 耐震性向上 および貯蔵密度向上の改良を行った．また，キャニスタ内伝熱流動実験を実施し，キャニスタ内のへリウムの自然対流 が使用済み燃料の除熱に寄与し，また，キャニスタ内圧を高めることで効果が促進されることを確認した．この結果よ り，キャニスタにはヘリウムを充填し，加圧することとし，設計に反映した .

米国での実績に加え，本研究の成果により横型サイロ貯蔵方式の使用済み燃料貯蔵施設の日本での適合性を確認でき た。

Keywords: 軽水炉，使用済み燃料，使用済み燃料中間貯蔵，使用済み燃料貯蔵施設，横型サイ口貯蔵方式，キャ二 スタ，コンクリートサイロ，伝熱流動

The Horizontal Modular Storage System is the dry storage system for the spent nuclear fuel, which was developed in the USA. It is one of the candidacy concepts for the interim spent fuel storage facility installed at away from reactor in Japan. We performed the conceptual design to reduce cost and to meet Japanese safety guidelines, rules and standards, fuel specifications and seismic conditions.

To meet Japanese conditions, the heat removal characteristic, the shielding characteristic, the aseismic characteristic and the required space are improved.

We also performed the experiments of the thermal hydraulics in the canister to confirm the heat removal characteristic of the system. The results show that the natural convection of the helium in the canister is effective to remove the residual heat from the spent fuel and the effect is improved when the helium is pressurized.

The storage experience in the USA and the results of this study show, the Horizontal Modular Storage System is acceptable for the interim spent fuel storage facility installed in Japan. .

Keywords: LWR, spent nuclear fuel, interim storage, spent fuel storage facility, horizontal modular storage system, canister, concrete module, thermal hydraulics

1 はじめに

我が国では発電所外の使用済み燃料中間貯蔵施設を 2010 年までに利用できるようにすることが必要である とし，国および電力会社を中心に，中間貯蔵施設の実現 に向けた準備が進められている .

米国で開発された軽水炉の使用済み燃料乾式貯蔵シ ステムであり, NUHOMS システム[1]として知られてい る横型サイロ貯蔵施設は，1989 年に H.B.Robinson 原子 力発電所に採用されて以来, 2002 年末時点で米国内 13 ヶ所の原子力発電所内の使用済み燃料貯蔵施設 (ISFSI) に採用され，关のうち 8 ヶ所の発電所では既に貯蔵が行 われている .Fig.1 は乥のうちの一つである Rancho Seco 発電所 (カリフォルニア州) に設置された横型サイロ貯 蔵施設 (NUHOMS-24P) である。

本報告では，日本の安全審査指針・技術基準，貯蔵 燃料の仕樣, 耐震条件等との適合性を考慮して設計した 横型サイロ盯蔵施設の概要およびキャニスタ内伝熱流 動実験の概要について紹介する .

Conceptual design of the horizontal modular storage system for spen nuclear fuel by Ryogo Minami (minami@nupec.or.jp), Tetsuo Nakata, Nobuyuki Takahashi

*川崎重工業株式会社 パワープラント事業部 開発部

Reserch \& Development Department Power Plant Division Plant \& Infrastructure Engineering Company Kawasaki Heavy Industries, LTD

于 136-8588 東京都江東区南砂 2-11-1

** 川崎重工業株式会社 関東技術研究所 先進材料研究部

干 136-8588 東京都江東区南砂 2-6-5

Kanto Technical Institute, Kawasaki Heavy Industries, Ltd.

\section{2 横型サイロ貯蔵施設の概要}

\section{1 設備の構成}

横型サイロ貯蔵施設は，使用済み燃料をステンレス 鋼製のキャニスタに収納し，鉄筋コンクリート製のコ ンクリートサイロ内に水平に貯蔵するコンクリートモ ジュール方式の使用済み燃料乾式貯蔵システムである. コンクリートサイロ 1 基とキャニスタ 1 基からなるモ ジュールを複数基並べて設置することにより貯蔵施設 が構成される .

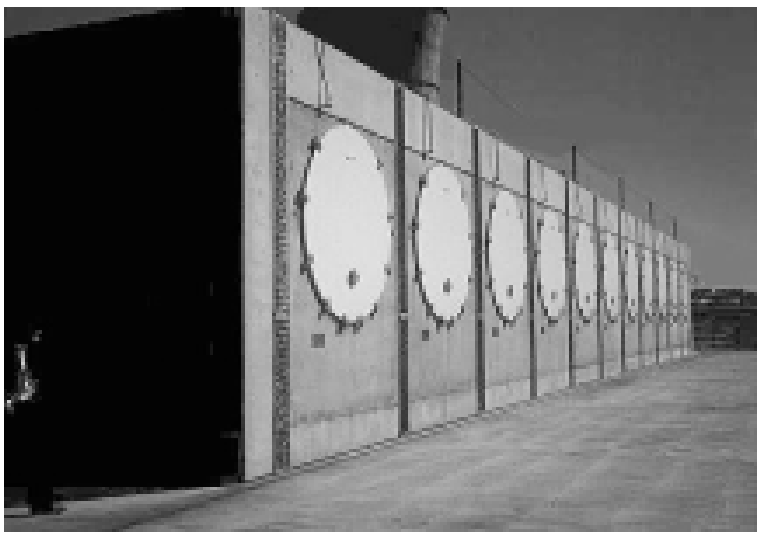

Fig.1 NUHOMS-24P Spent Fuel Horizontal Storage System at Rancho Seco Nuclear Power Station 


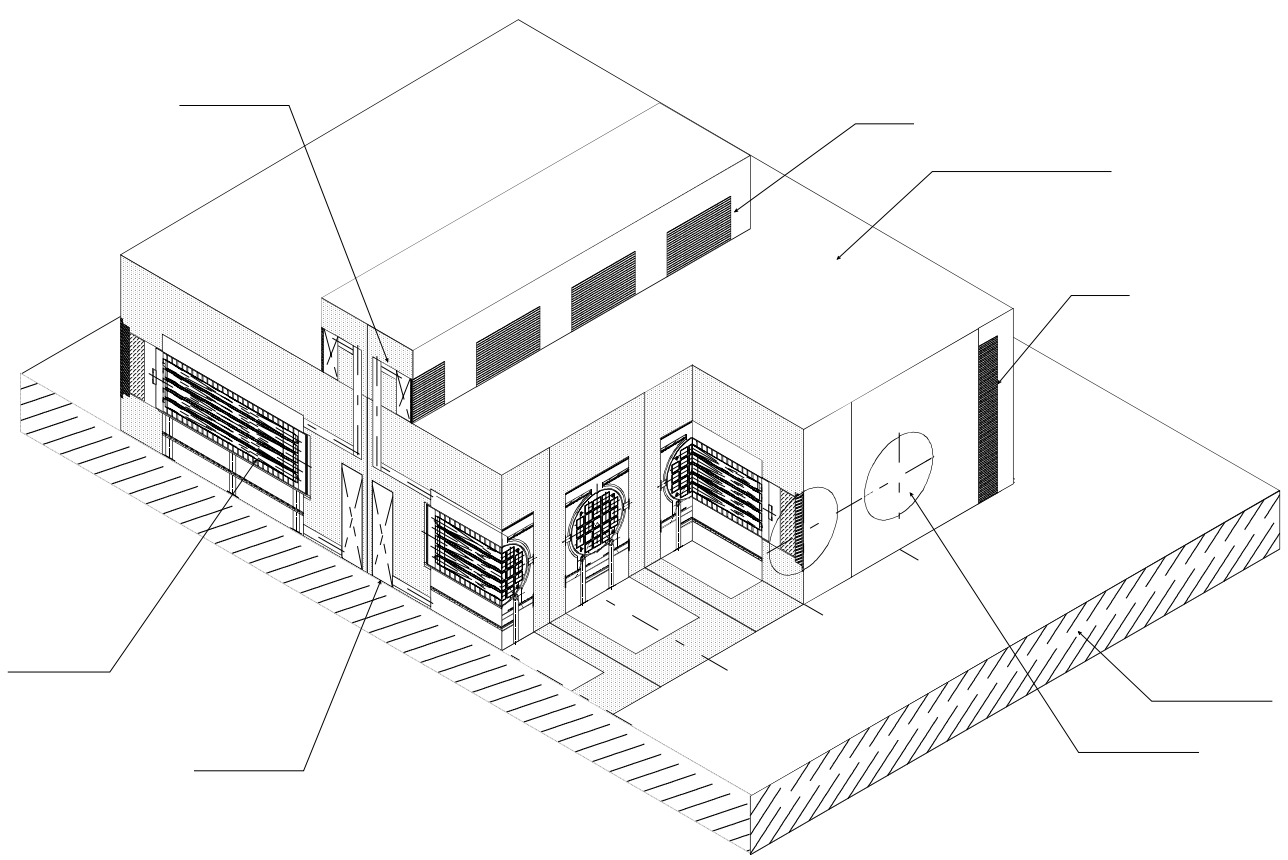

Fig.2 Concept of the Horizontal Storage System for Japanese Storage Facilities

Table 1 Specifications of the horizontal storage system for Japanese storage facilities

\begin{tabular}{|c|c|c|c|}
\hline \multicolumn{2}{|c|}{ 項 目 } & PWR & BWR \\
\hline \multirow{2}{*}{ 燃 } & 冷却年数 & \multicolumn{2}{|l|}{ 5〜 10 年 } \\
\hline & 発熱率 & 約 $1 \mathrm{~kW} /$ 体 & 約 $0.4 \mathrm{~kW} /$ 体 \\
\hline \multirow{6}{*}{$\begin{array}{l}\text { キ } \\
\text { D } \\
\text { 文 } \\
\text { 多 }\end{array}$} & 型式 & \multicolumn{2}{|c|}{ 両端遮へい付き円筒密封容器 } \\
\hline & $\begin{array}{l}\text { 使用済燃料 } \\
\text { 収納体数 }\end{array}$ & 24 体 & 52 体 \\
\hline & 直径 $\times$ 全長 & 約 $1.7 \times 4.7 \mathrm{~m}$ & 約 $1.7 \times 5.0 \mathrm{~mm}$ \\
\hline & バスケット形式 & \multicolumn{2}{|c|}{ スペーサディスク型 } \\
\hline & キャニスタ材質 & \multicolumn{2}{|c|}{ ステンレス鋼 } \\
\hline & 固定中性子吸収体 & BORAL 等 & B-SUS 等 \\
\hline \multirow{4}{*}{$\begin{array}{l}\text { サ } \\
\text { イ } \\
\text { 口 }\end{array}$} & 型 式 & \multicolumn{2}{|c|}{ 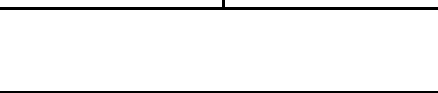 } \\
\hline & 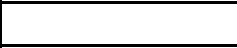 & \multicolumn{2}{|l|}{1 体/口०० } \\
\hline & 冷却方式 & \multicolumn{2}{|l|}{ 自然通風冷却 } \\
\hline & 幅× 高さ× 奥行 & \multicolumn{2}{|l|}{ 約 $3 \times 7 \times 7 \mathrm{~m}$} \\
\hline
\end{tabular}

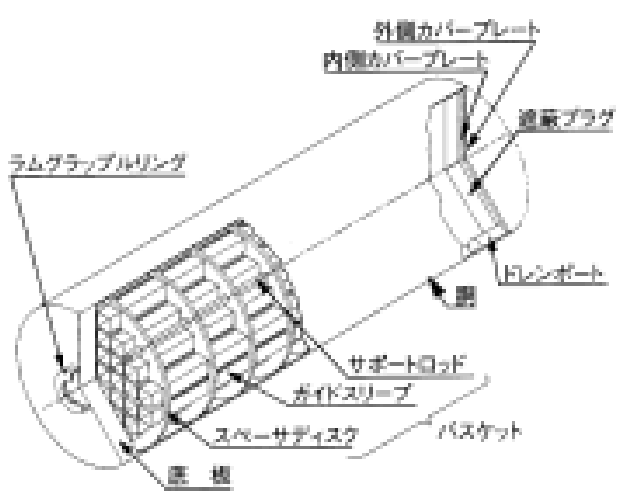

Fig.3 Concept of Canister
日本の安全審査指針・技術基準，貯蔵燃料仕樣，耐 震条件等との適合性を考慮して設計した横型サイロ貯 蔵施設の概念例を Fig.2 に, 光の概略仕樣を Table 1 に 示す.

キャニスタは直径約 $1.7 \mathrm{~m}$ ，長さ約 $5 \mathrm{~m}$ のステンレス 鋼製円筒容器で, 燃料プールで 5〜10 年冷却した使用 済み燃料を 1 基当たり PWR 燃料 24 体まで，または BWR 燃料 52 体まで貯蔵が可能である.キャニスタの 概念例を Fig.3 に示す . 内部にスペーサディスク , サポ ートロッドおよびガイドスリーブで構成されたバスケ ットを有しており，ガイドスリーブ中に使用済み燃料 を貯蔵する．キャニスタの蓋は二重とし，溶接で本体 に取り付け, 密封される.内部は燃料被覆管を保護す るため, ヘリウムが充填される .

\section{2 横型サイロ貯蔵施設の特徵}

横型サイロ貯蔵施設は使用済み燃料を安全な状態に 維持し，周辺公衆への影響を最小とするよう設計され ている、横型サイロ貯蔵施設の特徵を Table 2 に, 安全 設計の考え方を Table 3 に示す．

本施設は，コンクリートサイロ内を自然通風で流動 する空気で使用済み燃料を冷却し，燃料被覆管温度を 制限温度以下に維持する受動的な冷却システムを有し ており，送風機のような動的な機器がないため，メン テナンスがほとんど不要で, 貯蔵中は放射性廃棄物の 発生もなく，運転維持費が小さい．また，コンクリー トサイロ自体で遮へいを構成しているため, 少ない資 本費で建設することができる．

貯蔵施設はモジュール化されており，モジュールの 数は, 貯蔵容量に合わせて自由に選定可能である . こ のため, 小規模の発電所内貯蔵設備から, 大規模の敷 
地外中間貯蔵設備まで適用できる．また数基ずつ段階 的に増設していくことが可能で，建設工期が短いこと から, 使用済み燃料の発生にあわせ, 必要な時期に必 要な基数だけ逐次増設していくことができるフレキシ ビリティーのある貯蔵システムである．

\section{Table 2 Charactaristics of the Horizontal Storage System}

- モジュール方式

・貯蔵容量のフレキシビリティ

貯蔵必要量に合わせ、基数を自由に設定可能

・増設が容易

貯蔵需要に合わせ、段階的に増設可能

・建設工期が短い

- 使用済み燃料の自然通風冷却

・故障要因が少ない

・ 非常用電源不要

・運転維持費が少ない

動的な機器がなく、保守点検が容易

- 遮へい機能の分担によるコスト低減

・輸送時 : 鋼製キャニスタ輸送キャスクを 繰り返し使用可能

・貯蔵時 : 安価なコンクリート

・ キャニスタの溶接による密封

・フランジ構造に比べ、構造簡素

・一般に、高い密封性の確保可能

- 既設設備の活用(原子炉建屋内て燃料装荷)

- 燃料装荷 : 使用济み燃料貯蔵プール

· 使用済み燃料取扱：燃料交換機

・キャスク取扱：原子炉建屋天井クレーン

- 水平輸送、水平貯蔵

・キャニスタ取扱高さが低い

- 放射性廃棄物の発生量少

・貯蔵中、貯蔵施設からの放射性廃棄物発生なし

、廃止措置が容易

・モジュール方式であり、解体・撤去が容易

・貯蔵中、コンクリートの污染がない

\section{3 燃料装荷手順}

横型サイロ貯蔵施設の燃料装荷手順を Fig.4 に示す。 キャニスタへの燃料装荷は，一般的な使用済み燃料輸 送キャスクへの装荷と同樣に, 原子力発電所の使用済 燃料プール中で既存の燃料取扱機器を用いて行われる. 使用済み燃料を装荷したキャニスタは, プールより取 り出したのち, 燃料取扱建屋にて蓋を溶接し, 密封さ れる.さらに, 内部の水の排出, 真空乾燥およびへリ ウム充填をおこなった後, 移送台車にて貯蔵施設まで 運搬し, コンクリートサイロ内に貯蔵される.キャニ スタ自体は遮へい機能を持たないため, 使用済み燃料 プールから貯蔵施設まで運搬する間は, 遮へいを構成 する金属製のキャスクに収納して取り扱われる．

\section{4 日本の安全指針吱術基準との適合性}

横型サイロ貯蔵施設の設計に当たっては安全審査指 針・技術基準，貯蔵燃料の仕樣，耐震条件等の設計条 件などの日米の相違により，横型サイロを日本国内人 導入した場合の成立性の確認が必要であるため日本の 基準への適合性を評価し，安全性を確認した．日本の 基準に適合させるために加えた設計の主な改良点を以 下に示す。

(1) 除熱性向上 :

日本では, 米国に比べ燃料被覆管の許容温度が厳しい． (米国の横型サイロ貯蔵施設の例では PWR $384^{\circ} \mathrm{C}$ ，

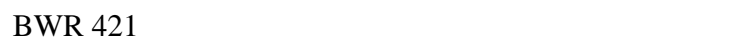
では PWR $370^{\circ} \mathrm{C}$, BWR $390^{\circ} \mathrm{C}$ ，また米国では移送時 等の短期間の事象に対しては $570^{\circ} \mathrm{Cを}$ 適用) また，発 熱の大きい燃料の貯蔵が想定される.このため本設計 では天井部に高さ約 $2 \mathrm{~m}$ のスタックを設け , 外気とコ ンクリートサイロ内の空気の温度差によって生じる

Table 3 Safety Features of the Horizontal Storage System

\begin{tabular}{|c|c|c|}
\hline 安全機能 & 評価基準 & 設計の考え方 \\
\hline 除熱 & $\begin{array}{l}\text { ·貯蔵中および構内移送時に燃料被覆管最 } \\
\text { 高温度か許容温度以下であること } \\
\text { ・コンクリート等、安全機能を有する構成部 } \\
\text { 材が想定される異常事象に対しても許容 } \\
\text { 温度以下であること }\end{array}$ & $\begin{array}{l}\text { 1) 貯蔵中 } \\
\text { (1)キャニスタ内 : 放射、伝導、ヘリウムの対流 } \\
\text { (2)コンクリートサイロ内 : 自然通風冷却 } \\
\text { (3)吸排気温度監視 } \\
\text { 2) 構内移送/事業所外運搬時 } \\
\text { (1)キャニスタタ内 : 放射、伝導、ヘリウムの対流 } \\
\text { (2)キャスク外面 : 自然対流 }\end{array}$ \\
\hline 密封 & $\begin{array}{l}\text { ·貯蔵中および構内移送時の異常事象に対 } \\
\text { してもキャニスタの発生応力が許容応力 } \\
\text { 以下であること }\end{array}$ & $\begin{array}{l}\text { 1) 燃料被覆管およびキャニスタによる2 重密封 } \\
\text { 2) キャニス } 2 \text { 重蓋のシール溶接 } \\
\text { 3) 漏洩監視不要(溶接の健全性で担保) }\end{array}$ \\
\hline 遮へい & $\begin{array}{l}\text { ・コンクリートサイロ、キャスク表面および } \\
\text { 貯蔵施設敷地境界線量当量率が許容線量 } \\
\text { 当量率以下であること }\end{array}$ & $\begin{array}{l}\text { 1) 貯蔵時 } \\
\text { (1)サイロ・コンクリート壁および遮へい蓋 } \\
\text { (2)吸排気口屈曲によるストリーミング抑制 } \\
\text { (3)貯蔵区域空間線量当量率連続監視 } \\
\text { 2) 構内移送時 } \\
\text { (1)キャスク構造部材およびY 線、中性子遮へい体 }\end{array}$ \\
\hline 臨界防止 & $\begin{array}{l}\cdot \text { 想定される異常事象を考慮しても中性子 } \\
\text { 実効増倍率 }\left(\mathrm{k}_{\mathrm{eff}}\right) \text { が } 0.95 \text { 以下であること }\end{array}$ & $\begin{array}{l}\text { 1) バスケットにより貯蔵体系維持 } \\
\text { 2) 必要に応じ中性子吸収材(BORAL,B-SUS等) }\end{array}$ \\
\hline
\end{tabular}


(1) 輸送キャスクをサイロへ移動

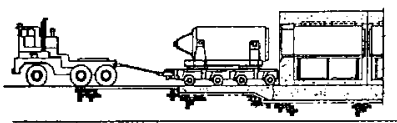

(2) 輸送キャスクとサイロを接続

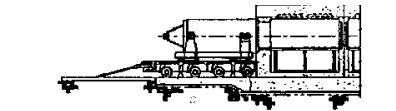

(3) キャニスタ装荷装置を取付け

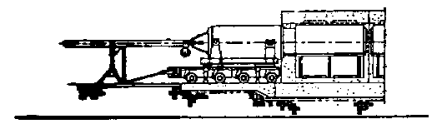

(4) キャニスタをサイロに装荷

(5) サイロ蓋取付け
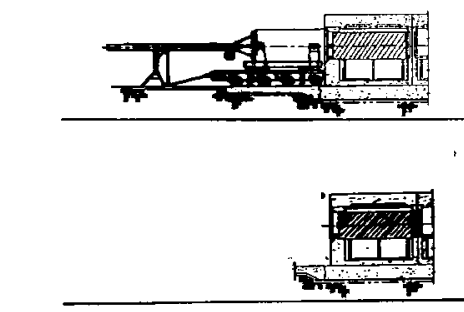

サイロ貯蔵施設

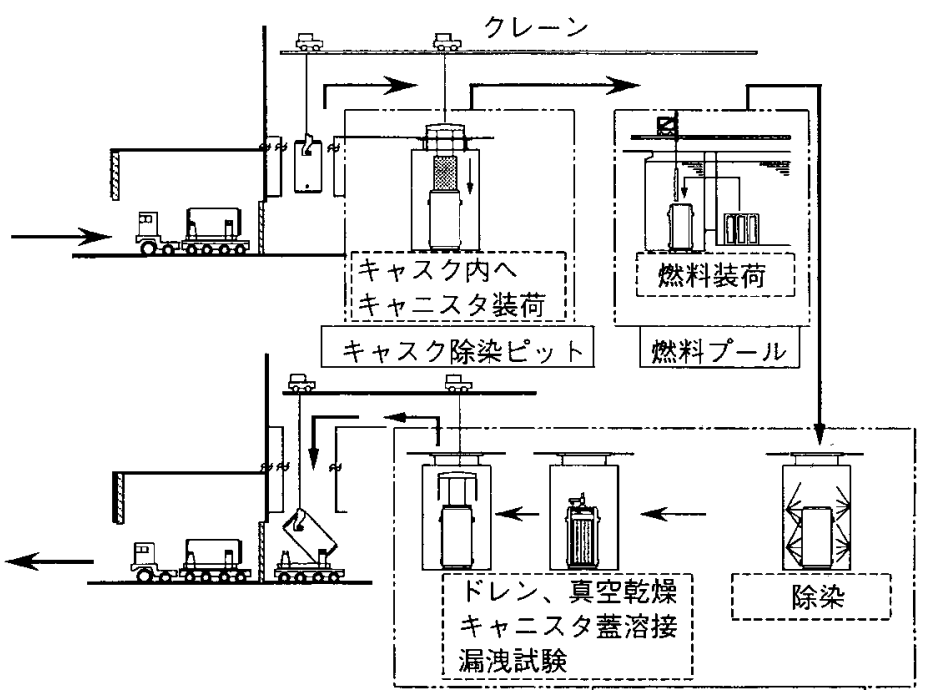

原子炉建屋

Fig.4 Handling Flow of the Horizontal Storage System

ドラフトカを十分とることで自然通風冷却空気流量 を確保し，発熱の大きい燃料の貯蔵を可能とした。

(2) 遮へい性能向上:

コンクリートサイロの表面線量当量率は米国では輸 送キャスク ( $2 \mathrm{mSv} / \mathrm{h}$ 以下) なみとしているが , 作業従 事者および周辺公衆の被ばくをできる限り小さくする ため, コンクリートサイロの壁厚を $1.5 \mathrm{~m}$ とし , 表面線 量当量率が非管理区域なみ $(6 \mu \mathrm{Sv} / \mathrm{h}$ 以下) となるよう 設計した．また，吸排気ダクトを屈曲構造とし，吸排 気口近傍のストリーミング線量も非管理区域なみとな るよう設計した。

以上の改良により本設計では貯蔵建屋等の補助遮へ いなしで敷地境界の線量率を基準値以下にすることが 可能である .

(3) 耐震性向上 :

米国の一般的な条件では考慮すべき地震力は水平方 向 $0.25 \mathrm{G}$, 鉛直方向 $0.17 \mathrm{G}$ であるが,日本国内ではより 大きな地震力が想定されるため，コンクリートサイロ の壁厚を十分厚くするとともに本体の高さは $4.8 \mathrm{~m}$ と， できる限り高さを低くした . なお，米国ではプレハブ 式のコンクリートサイロが開発されているが , 本設計 では基礎と一体で建設する構造とし，十分な耐震性を 持たせた .

(4) 貯蔵密度向上 :

国内の立地点の敷地面積が限られると予想されるた
め，多段式のキャニスタ装荷装置の採用等により，コ ンパクトな配置を実現した。

3 キャニス㐻伝熱流動試験

横型サイロ貯蔵施設の除熱性能を把握するため， Table 4 に示す一連のキャニスタ内伝熱流動試験 [2-7] を実施した . 得られた結果の概要は以下の通りである.

(1)基礎特性試験では, ヒータの発熱量を $45 \mathrm{~kW}$ に維持 し ,キャニスタ内圧を真空 $\left(1.3 \times 10^{-3} \mathrm{~Pa}\right)$,低圧 $(670 \mathrm{~Pa})$ ， 中圧 (0.14MPa) および高圧 $(0.45 \mathrm{MPa})$ として, キ ヤニスタ各部の温度を計測した .Fig.5に示すように， キャニスタ内のへリウムガス圧力が高くなるに従い， キャニスタ中心部の温度分布が上下非対称となると

Table 4 Experiments of the thermal hydraulics in the canister

\begin{tabular}{|c|c|c|c|}
\hline 項目 & 基礎特性試験 & 可視化試験 & 実機模擬言式験 \\
\hline \multirow[t]{4}{*}{ 目的 } & 放射、伝導、対 & 自然対流現象の & 実機模擬条件 \\
\hline & 流の基本特性 & 可視化技術によ & 下での解析モ \\
\hline & 把握およひ澥 & る特性把握およ & デル検正 \\
\hline & 析モデル検正 & $\begin{array}{l}\text { ひ解析モデル } \\
\text { の反映 }\end{array}$ & \\
\hline 流体 & $\begin{array}{l}\text { 真空 } 10000 \\
\text { (低/高圧) }\end{array}$ & 空気口水 & $\begin{array}{c}\text { 真空 } \\
\text { 混合ガス }\end{array}$ \\
\hline प्र०० & $1 / 4$ & $1 / 5$ & $1 / 4$ \\
\hline 対象 & PWR 24 体 & PWR 24 体 & PWR 24 体 \\
\hline
\end{tabular}



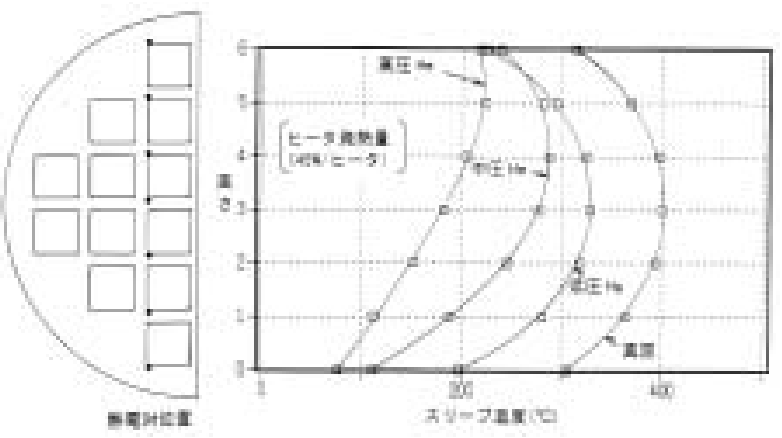

Fig.5 Temperature Distribution at the Center Line of the Canister at Various Helium Pressures

ともに,最高温度が大きく低下し，除熱が促進されて いることが確認できた .これは，高圧になるに従いキ ヤニスタ内の自然対流が大きくなり，自然対流による 熱輸送量が増大しているためと考えられる．

(2)可視化試験では，キャニスタ内自然対流の流速分布 を定量的に計測した .キャニスタ内の流体は空気また は水とし，流体が空気の場合はステアリン酸亜鉛で， 水の場合はポリスチレン粒子で流れを可視化し， Fig.6に示すような流況を得た。また，Fig.7に解析で 求めた流速および温度分布を示す 解析で求めた全体 の流況は試験結果とよく一致している .

(3)実機模擬試験では,レーリー数(Ra) $2 \times 10^{6} \sim 1.4 \times 10^{8}$ の範囲でキャニスタ内の温度分布を計測した . Fig. 8 に示すように ,キャニスタ内圧Pが増加するにしたが って, 温度差 $\Delta T$ (中央垂直ギャップに面するガイド スリーブ表面平均温度とキャニスタ内面の平均温度 の差) は指数関数的に減少し，両者は，

$$
\Delta \mathrm{T} \propto \mathrm{P}^{-0.3}
$$

という関係でほぼ整理でき,ガス圧力をある程度加圧 した場合は，自然対流による除熱効果が促進され，燃 料被覆管温度の低減に有効であることか確認できた 。

(4)可視化試験および実機模擬試験結果よりキャニスタ 内の伝熱相関式を求めた .レーリー数 $(\mathrm{Ra}) を 3 \times 10^{6}$ 〜2× $10^{8}$ の範囲で变化させた試験結果より，Fig.9に 示すように，

$$
\mathrm{Nu} \fallingdotseq 0.07 \sim 0.1 \mathrm{Ra}^{1 / 4}
$$

という結果が得られた .

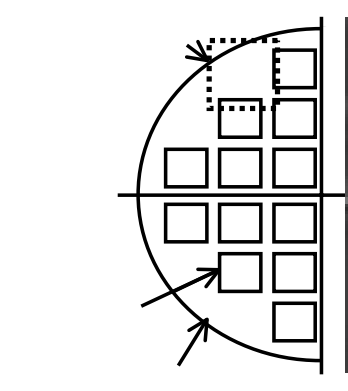

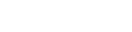

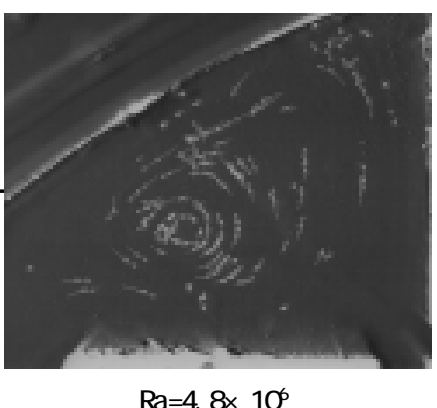

矢印は流れの方向を示す。
Fig.6 Flow Pattern in the Canister.(Visualization Test)
以上より，キャニスタ内のヘリウムの自然対流が使 用済燃料の除熱に寄与し，また，キャニスタ内圧を高 めることで, 除熱効果が促進されることを確認した . この結果より，キャニスタにはへリウムを充填し，加 圧することとし，設計に反映した .

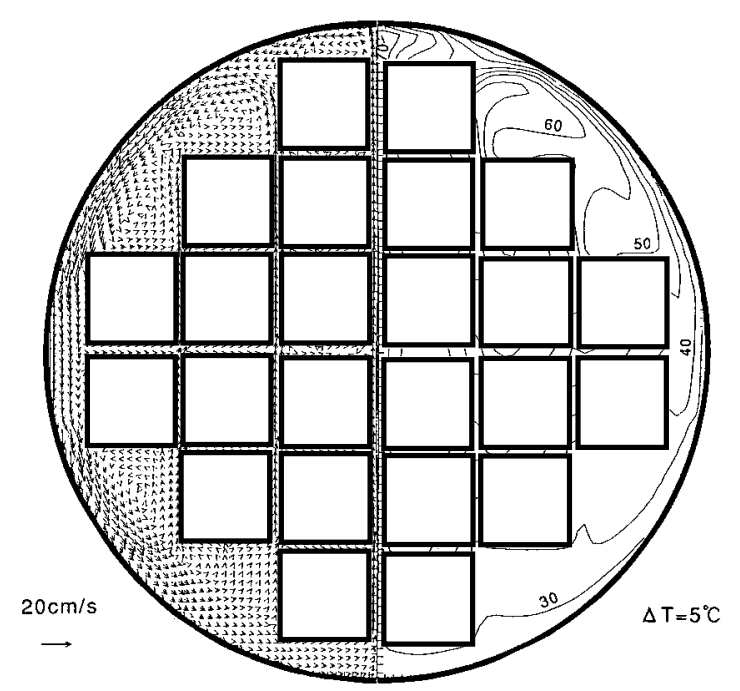

Fig. 7 Computation results of flow and temperature field (Ra $=9.3 \times 10^{6}$ Fluid: Air)

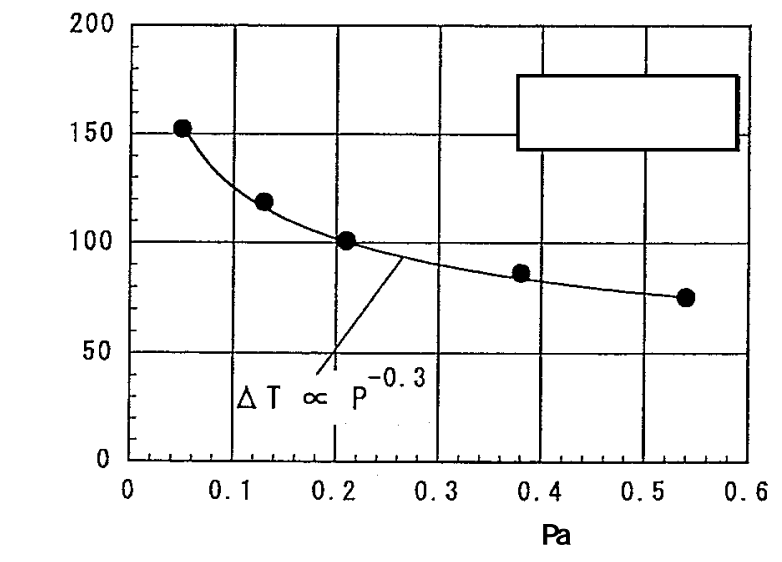

Fig.8 Relation between pressure and $\Delta t$ in the canister

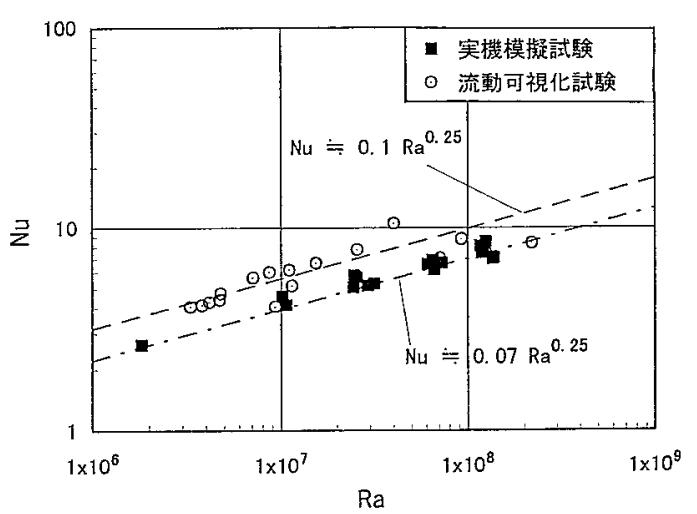

Fig.9 Heat Transfer Characteristics in the Canister 


\section{4 おわりに}

使用済燃料貯蔵施設として経済性が優れ，かつ高い 安全性を有するシステムの一つである横型サイロ貯蔵 施設の概念検討，安全評価を実施し，日本へ導入した 場合の安全性を確認するとともに , キャニスタ内伝熱 流動実験を実施し，使用済み燃料の除熱特性を把握し， その成果を設計に反映した。

米国での実績に加え, 本研究の成果により横型サイ 口貯蔵方式の使用済燃料貯蔵施設の日本での適合性を 確認できた .

\section{参考文献}

[1] VECTRA Technologies, Inc.: Safety Analysis Report for the Standardized NUHOMS ${ }^{\circledR}$ Horizontal Modular Storage System for Irradiated Nuclear Fuel, Revision 4A, (1996)

[2] Minami,R. et al.: A design Study of Horizontal Dry Storage System in Japan, The 1993 International Conference on Nuclear Waste Management and Environmental Remediation, Prague, September 5-11, 1993, Czrch Republic, pp.631-638 (1993)

[3] 高橋伸行 他 : 横型コンクリートサイロ貯蔵施設の 研究・第 1 報 (ふくく射伝熱を伴なう密閉容器内自然 対流試験)，第30回日本伝熱シンポジウム，横浜， 平成 5 年 5 月 27 日, pp.559-561，(1993)

[4] 西村元彦 他 : 横型コンクリートサイロ貯蔵施設の 研究・第 2 報 (放射伝熱を伴なう密閉容器内自然対 流の解析），機械学会第 71 期大会, 広島, 平成 5 年 10 月 2 日, pp.16-18，(1993)

[5] 西村元彦 他：横型コンクリートサイロ貯蔵施設の 研究・第 3 報 (放射伝熱を伴なう密閉容器内自然対 流の相似則に関する検討)，機械学会関西支部 第 69 回講演会論文集, pp.181-183，(1994)

[6] Shibazaki,H., et al.: Study on Natural Convection Heat Transfer in the Horizontal Dry Storage System for LWR Spent Fuel Assemblies, The 3rd International Conference on Nuclear Engineering, Kyoto, Japan, April 25, 1995, pp.95-100, (1995)

[7] 南了悟 他 : 使用济燃料横型サイロ貯蔵方式の除熱 性能評価，火力原子力発電，48-8, pp.48-56, (1997) 